\title{
A Deadly Digital Finger Dressing: A Case of Total Thumb Necrosis due to Circumferential Tight, Finger Dressing in a Child Patient
}

\author{
Parmakta Ölümcül Pansuman: Çocuk Bir Hastada Sirküler, Sıkı Pansumana Bağlı Gelişen \\ Total Başparmak Nekrozu Olgusu
}

\author{
(1) Yasin Öztürk ${ }^{1}$, (1) Kadri Özer ${ }^{2}$, (1) Oğuz Atan ${ }^{1}$, (1) Yüksel Kankaya ${ }^{1}$, (1) Melike Oruç ${ }^{1}$, (1) Uğur Koçer ${ }^{1}$ \\ ${ }^{1}$ Ankara Traning and Research Hospital, Clinic of Plastic Reconstructive and Aesthetic Surgery, Ankara, Turkey \\ ${ }^{2}$ Aydın State Hospital, Clinic of Plastic Reconstructive and Aesthetic Surgery, Aydın, Turkey
}

\section{To the Editor,}

Hand and wrist injuries are one of the most common injuries treated in emergency departments. Hand and wrist injuries have been reported to account for $4 \%$ to $28.6 \%$ of all emergency injuries. ${ }^{1}$ Most of these reported injuries have primarily involved the fingers (up to $62 \%$ ). ${ }^{1}$ In children under five years of age, fingertip injuries are most common comprising $38 \%$ of all fingertip injuries in children. After they are repaired, the wound is usually covered with a simple soft tissue dressing that is applied circumferentially around the digit by most clinicians. In children, this circumferential dressing may be rolled up the digit in a distal direction to create a tourniquet effect by a small manipulation which leads to ischemic conditions in the injured fingers. Ischemic pressure complications associated with digital dressings have been reported in the literature. However, this rare but serious complication could be prevented by attention while attempting a simple dressing. In the literature, it has been reported that $60 \%$ of cases resulted in amputation..$^{2,3}$ In all papers, the authors emphasized the importance of correct application of circumferential digital dressing and awareness of potential complications associated with vascular insufficiency from an occlusive dressing. ${ }^{4}$ It is very important to inform the patient's family about the dressing and dressing-related complications. We herein, present a case of arterial and venous perfusion loss and ischemic necrosis associated with circumferential dressing. The aim of this paper was to draw attention to extremity injuries particularly in children and discuss strategies that can be develop for the prevention of finger necrosis associated with improperly applied tubular dressing.

A 2-year-old patient who sustained total necrosis of the thumb distal phalanx was referred to our outpatient clinic. Anamnesis revealed that the patient was injured three days ago and after the injury, a circumferential gauze dressing was applied by her mother without applying to a health care center. During these three days, the dressing had not been changed. The discomfort that upset the child and caused crying was considered by the mother to be pain due to injury. She was referred to the plastic surgery clinic 72 hours after the first injury. When we performed the first examination of left thumb, we found a demarcation zone on the interphalangeal joint. There was no perfusion and sensation on the distal part of the demarcation zone. The soft tissue and bone tissue of the distal phalanx were not suitable for finger salvage and reconstructive surgery. Consequently, the distal phalanx of left thumb was evaluated as total necrosis (Figures 1, 2).

The decision for amputation was taken by the plastic and reconstructive surgery team because it was not possible to salvage the thumb. Eventually, the thumb was debrided by terminating just proximal to the interphalangeal joint and primarily closed with a local soft tissue. The stump healed uneventfully at the postoperative period.

There were many papers in the literature about the iatrogenic digital ischemia. Due to its rarity, this serious complication is often overlooked by clinicians. ${ }^{3,4}$ Most of the reported

Address for Correspondence/Yazışma Adresi: Yasin Öztürk MD, Ankara Traning and Research Hospital, Clinic of Plastic Reconstructive and Aesthetic Surgery, Ankara, Turkey E-mail: dr_yasin_oz@hotmail.com ORCID ID: orcid.org/0000-0003-2634-2677 Received/Geliș Tarihi: 03.03.2018 Accepted/Kabul Tarihi: 10.05.2018

- Copyright 2018 by Society of Pediatric Emergency and Intensive Care Medicine Journal of Pediatric Emergency and Pediatric Intensive Care published by Galenos Yayınevi. 


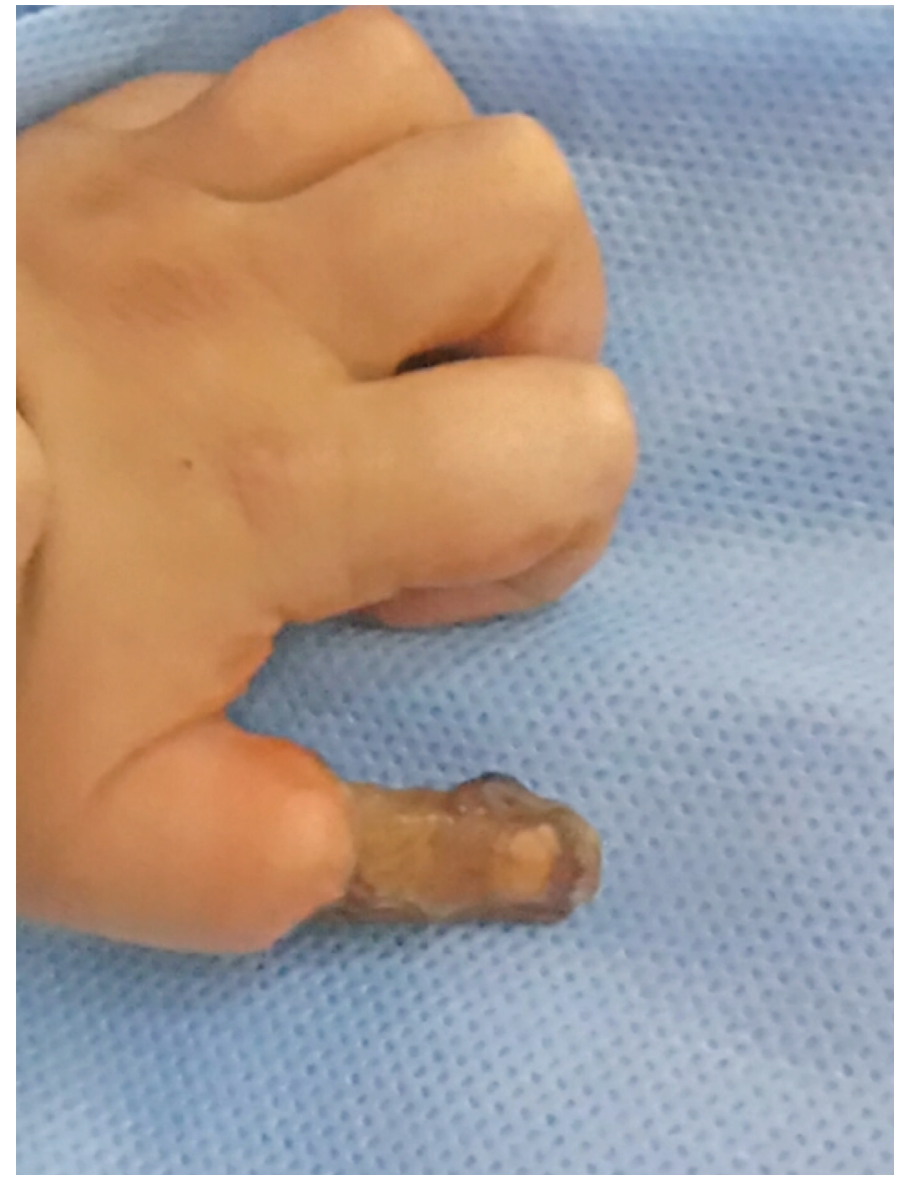

Figure 1. Dorsal aspect of full-thickness necrotic thumb and there was no blood perfussion on distal phalanx

ischemic finger cases were due to dressing include tubular gauze dressing. ${ }^{5}$

Miller and $\mathrm{Haftel}^{6}$ discussed four cases of digital ischemia due to improper elastic tubular gauze applications in patients with minor injuries. These gauze applications were highly unlikely to compromise finger viability, with one patient requiring amputation. ${ }^{6}$ A similar case that resulted in amputation because of multi-layering elastic tubular gauze was reported by Ersek.7 Neal reported a case of distal phalanx injury associated with tubular gauze dressing resulting in midproximal phalanx amputation. ${ }^{8}$ There were have been reports of digit amputation due to circumferential adhesive dressing and too tight "buddy-taping" application., 9,

Correct circumferential digital dressing application is a very important especially in child patients. It should be kept in mind that vascular insufficiency from an occlusive dressing is an iatrogenic and avoidable complication. Increasing pain is usually an alarming sign of a tight dressing. Patients should be instructed to remove the dressings in such alarming situations and return for re-examination. ${ }^{4}$ The first treatment option for this severe complication includes removal of the occlusive

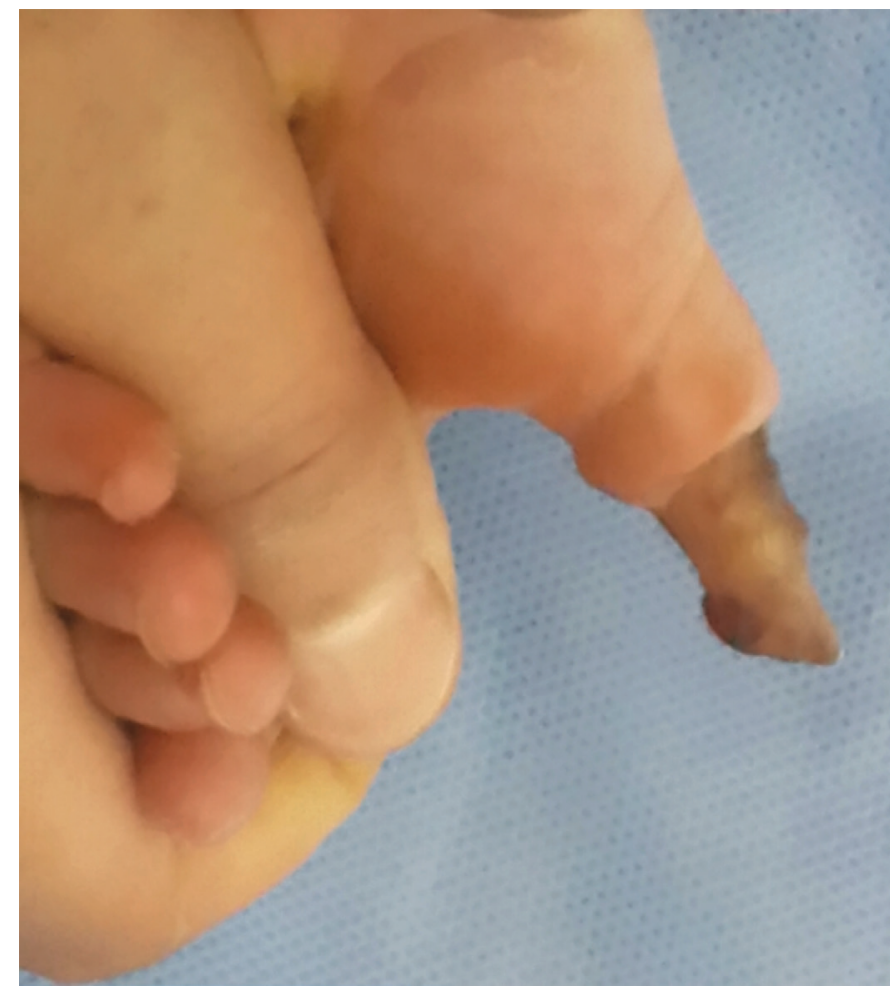

Figure 2. Volar aspect of necrotic thumb

dressings and observation of the ischemic fingers. The final treatment is the debridement of non-viable tissues, including digital amputation if necessary. ${ }^{4}$

In such ischemic fingers, the dressing should be opened immediately and devitalized tissues should be debrided and viable tissues should be protected as much as possible.

In this case report, successful operative decompression to improve the circulation was not possible because of fullthickness necrosis of the distal phalanx due to late arrival at the hospital. The final treatment was done by excision of the nonvital tissue of the thumb just proximal to the interphalangeal joint and primarily closing with local soft tissue.

Our experience with this case highlights how important a simple dressing is to prevent serious complications while performing even minor procedures. All physicians and their staff should be aware of the potential risk of the tourniquet effect of a dressing and take precautions with keeping in mind the fact that the best treatment for a complication is prevention. Increased physician awareness of this serious but potential problem is mandatory for prevention. Successful operative decompression is indicated in early cases to reduce tissue loss and optimize circulation, however, it may be too late for some patients for salvage surgery and most of those patients may undergo amputation of the necrotic part.

Keywords: Deadly, dressing, finger, necrosis

Anahtar Kelimeler: Ölümcül, pansuman, parmak, nekroz 


\section{Ethics}

Peer-review: Internally peer-reviewed.

\section{Authorship Contributions}

Surgical and Medical Practices: Y.Ö., Concept: Y.Ö., O.A., K.Ö., Design: Y.Ö., Y.K., Data Collection or Processing: Y.Ö., O.A., Analysis or Interpretation: Y.Ö., O.A., Literature Search: M.O., Y.K., Writing: Y.Ö., K.Ö.

Conflict of Interest: No conflict of interest was declared by the authors.

Financial Disclosure: The authors declared that this study received no financial support.

\section{References}

1. Angermann $P$, Lohmann M. Injuries to the hand and wrist. A study of 50,272 injuries. J Hand Surg Br. 1993;18:642-4.

2. Fattah A. Dressed to kill: pressure necrosis secondary to finger dressing. J Plast Reconstr Aesthet Surg. 2006;59:105-6.
3. Hart RG, Wolff TW, O'Neill WL Jr. Preventing tourniquet effect when dressing finger wounds in children. Am J Emerg Med. 2004;22:594-5.

4. Spruiell MD, Messina MJ, Mitchell JJ, Scott FA. A deadly digital dressing: a case of surgical decompression for finger ischemia due to circumferential finger dressing. J Emerg Med. 2014;46:655-8.

5. Norris RL, Gilbert GH. Digital necrosis necessitating amputation after tube gauze dressing application in the ED. Am J Emerg Med. 2006;24:618-21.

6. Miller TA, Haftel AJ. latrogenic digital ischemia. West J Med. 1975;122:183-4.

7. Ersek RA. Ischemic necrosis and elastic net bandages. Tex Med. 1982;78:47-9.

8. Neal JM. latrogenic digital ischemia. Ann Emerg Med. 1986;15:3823.

9. Heather J, Bisson M. Constriction "Band-Aid" syndrome causing digital ischaemia. N Z Med J. 2011;124:107-10.

10. Rashid A, Ahmed OA, Diver AJ, Basheer MH, Herbert KJ. Love thy neighbour-a case report of fingertip necrosis following neighbour strapping. Injury. 2005;36:220-1. 